\title{
Hamlet hears Marlowe; Shakespeare reads Virgil
}

JAMES

BLACK

Summary: The excerpt from Aeneas' tale to Dido which Hamlet elicits from the Player is based in part on Marlowe's Dido Queen of Carthage. As a melodramatic description of the culmination of the Trojan war with the slaughter of Priam, the Player's speech appears to be specified by Hamlet because it recalls Old Hamlet's preceding account of his own murder - a report which figures Old Hamlet's body as an assailed citadel. These two accounts, with other Virgilian and contemporary allusions, associate the action and apparent inaction of Hamlet with the manoeuvres and stalemates of an extended siege war. Elizabethan land warfare was chiefly siege campaigning, and there was an extensive contemporary literature on this mode of conflict. Marrying Virgil's account of Troy to Renaissance siegecraft theory, Shakespeare makes the Aeneid and elements of contemporary warfare an entelechy of Hamlet.

\section{D}

onna B. Hamilton has recently analyzed how Shakespeare, in The Tempest, appropriated the language of Virgil - especially the Aeneid - for Jacobean political issues and perspectives. ${ }^{1} \mathrm{I}$ am interested here in what appears to be a more localized Shakespearean "investment in Virgil's text": ${ }^{2}$ the Player's speech in Hamlet II.ii. I intend to argue that Shakespeare's use (or since he borrowed from an intervening text by Christopher Marlowe and Thomas Nashe, his re-use) of the Aeneid in Hamlet creates for both Virgil's epic and Hamlet "a special sense and understanding of [their] reader, listener, [or] public."3

Hamlet asks the Player for a "taste of [his] quality, . . . a passionate speech," and nominates a speech he heard the Player speak once from a play 
18 / Renaissance and Reformation / Renaissance et Réforme

that "was never acted, or, if it was, not above once. [. . .] One speech in it I chiefly loved, 'twas Aeneas' tale to Dido, and thereabout of it especially where he speaks of Priam's slaughter" (II.ii. 426-27, 437-39). ${ }^{4}$ In his request Hamlet implies (and Shakespeare assumes) a general familiarity with this part of the Aeneid - a reasonable assumption because the first six books of Virgil's epic circulated in several Tudor translations, and Books 1,2,4 and 6 were study texts in grammar schools and universities. ${ }^{5}$ The speech also implies knowledge of its occasion and setting by being periphrastically - even comically allusive: "the ominous horse," "the parching streets," "the nobled queen." Though usually referred to as the Player's speech, its delivery is shared by Hamlet himself, for he gives a memorial reconstruction of the first thirteen lines. The Player continues for 43 more lines, on Priam's death and Hecuba's grief - all of which Hamlet is determined to hear, because he refuses to let Polonius stop the recitation and urges "Say on, come to Hecuba" (11.492-93). He knows exactly what he wants to hear again from this once-heard play: a tragic account of surreptitious entry - "couched in the ominous horse" - and assault on a sleeping citadel, the remorseless slaughter of a helpless king; and the frantic grief of the queen. With the exception of one detail (the queen's grief), the Player's speech is a topical rendering of the Ghost's story told to Hamlet in 1.5. Hamlet's commentary on the Player's speech in his following soliloquy dwells on the parallel "damned defeat" of his king and father.

Hamlet's claim that the play from which he wants a speech "was never acted, or if it was, not above once" is usually taken as referring to the stage experience of Marlowe's and Nashe's Dido Queen of Carthage, whose text is echoed in the Player's speech. Dido was published in 1594: the title page states that it is printed as acted by the children of Her Majesty's Chapel. There is no record of public performance: three 1598 entries in Henslowe's Diary for costumes and properties for "dido and eneas" have not been connected with performances of Marlowe's play by the Admiral's Men. In Hamlet the players are said to be on tour because boy actors are in fashion in the city, and commentators on Hamlet usually note that the Children of the Chapel had begun to play at the Blackfriars Playhouse in 1600.

Matters of performance history like this, and the easy assumption that Shakespeare is using an available and parody-able play by a well-known contemporary, have got in the way of consideration of what in fact this Player's speech is doing in Hamlet. The speech uses details that are in Dido and not in the Aeneid (2:559-7286): Priam's feeble attempt to struggle with Pyrrhus at close quarters; Priam being blown over by the wind of Pyrrhus' sword; Pyrrhus being interrupted - in Dido by Hecuba's attack on him, in Hamlet by the 
distraction of Troy crashing down in fire; the prolongation of the butchery of the old man; Pyrrhus standing like a statue (Dido) or a painting (Hamlet). But what the Player's speech mainly borrows from Dido, and heavily exaggerates, is the melodramatic tone. H.J. Oliver says that Shakespeare is "not quoting Marlowe but half-affectionately pushing over the edge of absurdity what was only trembling on the brink of it." In the Player's speech Hecuba does (even overdoes) what any tragic auditor would expect her to do; Hamlet insists on hearing this reaction narrated. Having invited this melodrama, in which he obviously identifies Pyrrhus with Claudius, he responds melodramatically in his soliloquy that follows, and rages that "ere this/I should have fatted all the region kites/With this slave's offal. Bloody, bawdy villain!/ Remorseless, treacherous, lecherous, kindless villain!" (II.ii.567-69). Harold Jenkins notes that the derivation of the "Player's speech is less important than its reproduction of the play's basic motifs in exaggerated style." ${ }^{\text {T }}$ The speech, along with the soliloquy that it inspires from Hamlet, is reflective of his state of despairing outrage. What he hears in the speech, and clearly knew he would hear, is a tumult of ancestral voices reminiscing and prophesying war.

The most immediate voice is the Ghost's. In the play's first of three (or three and a half, if we count the interrupted "Murder of Gonzago") accounts of king-killing, the Ghost told Hamlet a story very like Aeneas' tale to Dido:

Sleeping within my orchard,

My custom always in the afternoon,

Upon my secure hour thy uncle stole

With juice of cursed hebenon in a vial,

And in the porches of my ears did pour

The leperous distilment, whose effect

Holds such an enmity wi'th' blood of man

That swift as quicksilver it courses through

The natural gates and alleys of the body, And with a sudden vigor it doth posset

And curd, like eager droppings into milk,

The thin and wholesome blood. So did it mine.

And a most instant tetter barked about ...

All my smooth body.

(I.v.59-73)

The Ghost's account here draws on a number of Renaissance ideas, especially those ideas which "theorized the body." In the anthropomorphism of state and in literary trope, the monarch is the land. King James told Parliament that "in 
the Scriptures ... Kings are compared to the head of this microcosm of the body of a man." Anthropomorphic parallels had also become commonplace in Renaissance architectural treatises, following Vitruvius' dictum "that the body, the source of the circle and the square, was also the exemplar of the harmony and proportion to be observed in all correct building." 10 Postmodernist discourse of the body as site of conflict is anticipated in the language of Renaissance fortress planning. As J.R. Hale explains, "In the literature of fortification, and, indeed, in common parlance, bastions were compared to arms, their batteries to eyes, the lobed projections which protected them were called 'ears', 'shoulders', 'snouts', even - Pietro Cataneo put this down to the influence of the military - 'testicles."' 11

In Hamlet, the Ghost's description of how poison invaded his system is only one instance among many of a recurring figure - the individual as beleaguered and embattled in mind and body: "Whether'tis nobler in the mind to suffer/The slings and arrows of outrageous fortune,/Or to take arms against a sea of troubles/And by opposing end them" (III.ii.58-61). A cognate representation is of the individual as micro-fortress: Rosencrantz tells Claudius, "The single and peculiar life is bound/With all the strength and armour of the $\mathrm{mind} / \mathrm{To}$ keep itself from noyance" (III.iii.11-13); and Claudius reassures himself that "Divinity doth hedge a king" (IV.v.121).

Thus in the Ghost's story his violated ear is "the whole ear of Denmark/ [that has been] by a forged process of [his] death/Rankly abused" (I.v.36-38). And his ear is also a gateway or entrance ("porches") penetrated by an agency that "holds ... an enmity" and that swiftly courses through the gates and alleys of the body. Commentators who explain about the vena porta or gate-vein that conveys blood to the liver overlook the connection of enmity, penetration and urban inrush with a successful siege assault - an assault which in many of its elements makes the Ghost's story a precis of Troy's last hours. Hamilton says that "The key elements of the Trojan tragedy [are] conspiracy and sleep" and "an opening of city gates." I2 In Virgil, Aeneas' account of Troy's fall is full of assailants rushing through narrow streets to private and sacred places, of desperate onslaughts and defence. It culminates in the brutal slaughter of Priam in his domestic and religious sanctuary. The Ghost's tale to Hamlet of being treacherously invaded and rushed through parallels, modernizes and compresses Aeneas' tale. In Dido, Marlowe's imitation of Virgil, or continuation of epic by other means, consists mainly of translation (his own, apparently) and melodramatising paraphrase. Shakespeare's imitation of Dido retains the melodrama to "mark off this bit of a play-within-the-play from the play 
proper." 13 (Jenkins's edition prints it and "The Murder of Gonzago" in italic). Coming as it does after a long passage of prose in this scene of Hamlet, the florid style of the Player's speech suggests that Hamlet's experience including the Ghost's story - is "real", even though — in fact, because - the Ghost's story has the same topos as the account of Priam's murder. By incorporating that melodramatic passage Shakespeare does several things: he illustrates Hamlet's excitable state of mind; he gives an ironic sample of the kind of melodrama that Hamlet could be; in treating Priam's fate and Hecuba's reaction to it more or less separately (that is, clearly segmenting the Player's speech into "Priam" and "Hecuba") he emphasizes the separation that Hamlet sees between Old Hamlet and Gertrude. As a by-product (intentional or not) of this imitation of Dido, Shakespeare legitimizes the older play by quoting or reviving it in a context where it finds its ideal audience in Prince Hamlet, who considers it an effective rendering of both Aeneas' tale and the Ghost's story. Shakespeare has given the never-staged (so Hamlet says) older play what Bakhtin calls "addressivity, the quality of turning to someone, [which is] a constitutive feature of an utterance; without it the utterance does not and cannot exist."14

Perhaps in its nearly 400-year existence Dido Queen of Carthage has had only one ideal audience, and that audience is one character in a Shakespeare play. If Harold Bloom had not already exempted Shakespeare from the anxiety of influence because Shakespeare had nothing to fear from the precursor poet Marlowe, ${ }^{15}$ Shakespeare's use of Dido would be conclusive evidence that he had no such anxiety. In fact, by using a fragment of Dido Shakespeare pays Marlowe the compliment of making him and Virgil co-sources.

But more important than Hamlet hearing Marlowe (and Nashe) and Shakespeare reading and rewriting Virgil is consideration of why Shakespeare is rewriting a rewriting of parts of the Aeneid. Although, as Hamilton reminds us, "'imitation' in the Renaissance meant making something new from the art of another artist" and Virgil is "the poet whom [Shakespeare] . . confronted and [rewrote] almost obsessively throughout his career," 16 there are more than just imitative and metadramatic issues in the Player's speech. There is in fact an especial aptness to Shakespeare using Virgil's epic in his own tragedy.

It is a commonplace that Hamlet is a play filled with what used to be called imagery of warfare, and with rituals of combat, from its opening guard-change to the closing military funeral. A question that is not asked, but which, if asked, helps to answer the question of why the Aeneid is written into the play is: what kind of warfare is Hamlet about? A fact of early modern European history, including English history, is that land wars were conducted mainly as siege 
campaigns. In Elizabeth's reign land warfare took place mainly in Ireland (until 1603) and in the Low Countries. With the assistance of European military architects, Henry VIII, Mary and Elizabeth built fortresses on the English seacoast, the Scottish border and in Ireland to resist invasion and quell uprisings. ${ }^{17}$ Fortress-building and siegecraft were facts of life across sixteenthand seventeenth-century Europe, and held special fascination for the Renaissance mind. They involved techniques of offence and defence, gunnery and explosives, and the mathematical science that these techniques required; they also called out measures of human guile, and luck. Guile and luck often were the factors that tipped the balance in siege warfare, which by the late 1500 s tended towards logistical stalemate. In the early part of the sixteenth century the development of gunnery, especially in France, had given the advantage to attackers, but by the third quarter of the century techniques of fortification had caught up, so that offensive and defensive capabilities in most parts of continental Europe tended to be in equilibrium. The result could be siege operations of great length and complexity. In the Eighty Years War (15661648 ) in the Low Countries between the Dutch and the occupying Spanish, Haarlem resisted Spanish attacks for ten months before being starved into surrender in July $1573 .{ }^{18}$ Ostende held out against the Spanish for three years and 77 days before surrendering in September 1604. When the Spanish were beleaguered in the fortified town of Zutphen in 1583, the fighting around this stronghold went on for seven years. ${ }^{19}$ Leicester's expedition arrived at Zutphen in late 1586 and deadlocked there all winter. (Philip Sidney was wounded at Zutphen on 22 September 1586 and died on 17 October. There is no way of confirming or denying speculation that Shakespeare might have been in Leicester's army). ${ }^{20}$

Publications on military engineering and siege tactics began to appear early in Elizabeth's reign. The first English book on these subjects was Peter Whitehorne's Certain Ways for the Ordering of Soldiers in Battle Array ... and Also Figures of Certain New Plattes [Plans] for Fortification of Towns (1562). Two years before, in 1560, Whitehorne had published an English translation of Niccolò Machiavelli's 1521 treatise The Art of War. The translation was reprinted in 1573 and 1588. Book Seven of The Art of War is devoted to fortification and siegecraft. Other major English works on the subject were Thomas Digges's A Geometrical Practical Treatise Named Pantometrica (1571, reissued 1589) and The Practice of Fortification (1589) by one of the European engineers commissioned by Elizabeth to advise on English and Irish forts, Paul Ive. Parts of Ive's book were directly incorporated by Marlowe into 
The Second Part of Tamburlane, where in III.ii. Tamburlane gives his sons an outline of the science of building to withstand a siege. In the play, Ive's technical details of fortification are detailedly versified (giving a new currency to "Marlowe's mighty line"). And the same kind of technical language made into poetry is used by Shakespeare in Henry IV Part One, where Hotspur's wife recounts how he talks in his sleep, mostly in siegecraft terms, "Of sallies and retires, of trenches, tents/Of palisadoes, frontiers, parapets,/Of basilisks, of cannon, culverin" (II.iii.52-54). (The Shakespearean twist on this military recitation is that it is in a woman's voice, and Shakespeare gives her at least as much knowledge about early modern warfare as her husband has, because Hotspur's own military practice is totally medieval). The word "excursion" that we are accustomed to see in stage directions and take to mean something general like fighting or milling about belligerently means issuing or sallying from a defensive position.

Even when purveying technical and practical information Renaissance writers on war, like the imaginative writers, had wide fields of reference and few worries about being anachronistic. For instance, in the seventh Book of The Art of War, where he deals with matters of fortification, artillery, mines and subterranean passages, Machiavelli draws examples of strategy and discipline from classical authors like Frontinus and Caesar. Another example of this sort of anachronism can be seen in woodcuts illustrating John Lydgate's Troy Book, the 1513 translation ${ }^{21}$ of Guido della Colonna's Latin Historia destructionus Troiae (the purportedly-true accounts of Troy by Daretus, a Trojan, and Dictus, a Greek, discovered in Athens by della Colonna). The Troy Book illustrations depict "incidents" from the Troy siege, with men in medieval or Renaissance armour using cannon and mortars. Somewhere about the time when Shakespeare wrote Hamlet he read the Troy Book as one of the sources for Troilus and Cressida. With Homer and Virgil and Lydgate and contemporary Renaissance books in the imaginative and technical marketplace, it is not surprising to find Fluellen complaining in Henry V(III.ii.71-77) that the job of undermining the walls of Harfleur isn't being conducted according to "the Roman disciplines." Nor is it surprising that a Trojan horse and mines and countermines co-exist in Hamlet's thoughts or, given the anthropomorphic cast of military-architectural terminology, that the Ghost speaks of his body as an invaded fortress.

In Hamlet, then, by Shakespeare's rewriting of Virgil, by his rewriting of Marlowe's and Nashe's rewriting of Virgil, as well as by contemporary experience and contemporary literature about warfare, Hamlet's struggle has 
the elements of a siege war. Almost all of the many military gestures in the play have siege connotations, from the placing of guards in the first scene to the final entrance of Fortinbras, who, supposedly marching to Poland, has been circling like Joshua at Jericho. Siege business is in the poetry too: "Let us once again assail your ears,/That are so fortified against our story" (I.i.31-32); "Oft breaking down the pales and forts of reason" (I.iv.28). Polonius speaks of Hamlet as having been "repulsed" (Folio) or "repell'd" (Q2) by Ophelia whom Laertes formerly advised to "keep within the rear of [her] affection,/Out of the shot and danger of desire" (I.iii.34-35). Without noticing the pattern of siege terms, Jenkins reads Polonius's order that Ophelia "set [her] entreatments at a higher rate/Than a command to parley" as "Ophelia, as defender of a citadel, is not to accept the beseiger's call for a parley as a sufficient reason" to . . . enter into negotiations with him." ${ }^{22}$ Claudius feels bad news strike him like mortar fire: "This,/Like to a murdering piece, in many places/Gives me superfluous death" (IV.v.90-92). (Hamlet will kill him in three ways, any two of them superfluous). As the play begins, Denmark is arming and guarding in expectation of an assault from Fortinbras, but arms and guards are powerless against Claudius or against the martial figure of the dead king who moves about inside and below Elsinore as both general and "worthy pioneer" (I.v.171). In these manifestations of general and pioneer he straddles the range of ranks and functions in a siege army. Pioneers dug trenches and tunnels, laid mines, made and widened breaches.

The term "worthy pioneer" is used by Hamlet just after hearing the Ghost's story of how his bodily gates and alleys were invaded by the poison: "so did it mine" - is "mine" a possessive pronoun or a verb? The poison not only mines or rushes through the old king's body but also erupts with explosive speed and effect through his skin: "sudden vigour," "most instant." In opposing Claudius and protesting to Gertrude, Hamlet sets himself against "rank corruption, mining all within" (III.iv.144), and says his strategy is "to have the engineer/Hoist with his own petard; and't shall go hard/But I will delve one yard below their mines/and blow them at the moon" (Q2 III.iv.195-98). This is revenge-tragedy plot and counterplot put into siege-war terms. But whatever signifiers Hamlet himself may use, the hostilities in Denmark become a waiting and watching and listening game, essentially the action - or inaction - of sieges, where intelligence-gathering took on great importance. In Whitehorne's translation of Machiavelli the Book seven outline of fortification, mines and subterranean passages also gives advice about never trusting enemies' appearances, about drawing out a besieged garrison, corrupting and 
surprising a town, sending confidants to gain credit with the enemy and betray them, securing oneself against infidelity in one's own party, and poisoning defenders. ${ }^{23}$ In the play's stalemate, Claudius uses his listening-posts Polonius and Rosencrantz and Guildenstern - for all Hamlet knows, Gertrude and Ophelia as well. Hamlet sends back contradictory messages by responding to what each spy-theorist wants to hear (love-melancholy, ambition) - Sonnet 86 has a nice phrase for this procedure, gulling with intelligence. In the middle of the play the adversaries peer through the dark at each other, like the guards Barnardo and Francisco in the opening scene or as in Hamlet's description of his counter-espionage aboard ship where, "Up from my cabin,/My sea-gown scarfed about me, in the dark/Groped I to find out them" (V.ii.13-15). And Hamlet merges contemporary warfare and epic tale by drawing into Elsinore his own version of a wooden horse: "The Murder of Gonzago", an old play that he has redacted as both intelligence-gatherer and siege-engine (in Titus Andronicus the Trojan horse is called "the fatal engine", V.iii.85-87). Just before the dumb-show he laments that his father is forgotten, "with the hobbyhorse" (III.ii.117-26).

There are correspondences between characters in Hamlet and in the Aeneid, though the parallels are not always clear. In the Player's speech from the old play, Hamlet, by speaking the first thirteen lines, casts himself as the tale-teller Aeneas, the looker-on who saw Priam killed and did not intervene (it is tempting to hear word-play on "Aeneas" in his soliloquy just afterwards when he rages at himself for silence and inaction and says "Why, what an ass am I!" [II.ii.571]). Actually, implications flood out of the play-horse(s) (both Aeneas' tale and "The Murder of Gonzago"). Obviously Hamlet, casting himself as Aeneas in the old play, also casts his father as Priam, Claudius as Pyrrhus, and would like Gertrude to be Hecuba - "hearing Marlowe" turns Hamlet's life back into tidy art. To be fair to Dido Queen of Carthage, Aeneas is presented quite ironically there,${ }^{24}$ while Hamlet's memory of the speech he heard once is selective and has clear-cut characterizations. But outside his remembrance of Aeneas' tale to Dido, experience is more slippery, not so pat.

For Lucianus in "The Murder of Gonzago" is both Claudius and Hamlet, poisoner and avenger, just as Pyrrhus in the Player's speech was murderer of Priam and avenger of his father Achilles. Jenkins and others note that Pyrrhus is also imaged in Hamlet standing over Claudius ${ }^{25}$ and "[doing] nothing." Hamlet's melodramatic "Now could I drink hot blood" (III.ii.373) echoes the hyperbolic representations of Pyrrhus as comestible, cook or even cannibal when, covered with blood, he is "baked and impasted with the parching 
streets," is "roasted in wrath and fire" and is seen by Hecuba "mincing with his sword her husband's limbs" (II.ii.450,452,505). Is Hamlet a Pyrrhus when he kills Polonius? Or, given that he thinks it is Claudius behind the arras, is he momentarily an active Aeneas avenging Priam and defending Hecuba, as well as defending Gertrude-Hecuba (in her sanctuary) from Claudius-Pyrrhus? His reaction to an interloper in the Queen's domain is understandable in the context of Patricia Fumerton's explanation of how the Elizabethan self, especially the aristocratic self, constantly sought but never fully achieved "any final moment of privacy": "there never was any ultimate apartment, room, cabinet, or other apartment of privacy that could be locked away from the public; only a perpetual regress of apartments. "26 Leonard Tennenhouse compares Gertrude's body to the play within the play, where the two acts of treason are the political seizure of the kingdom and the erotic possession of the queen. ${ }^{27}$ Machiavelli points out that enemy penetration to the last centre of defence is effectively defeat for the besieged, and he adduces the example of a female defender:

Nothing can expose a fortress to greater danger than having places of retreat into which the garrison may retire when they are hard pressed ... Of this we have a recent and memorable instance in the loss of the citadel Forli, when the Countess Caterina was besieged there by Cesare Borgia ... That fortress was so full of such places of retreat that a garrison might retire out of one into another, and out of that into many more successively ... The governor, instead of defending [a breach made in the outer wall], retreated into another division; thereupon the duke's forces immediately entered that division without opposition and, having got possession of the drawbridges, soon made themselves masters of all the rest. ${ }^{28}$

Hamlet's most desperate and futile act on behalf of the Ghost and Gertrude is committed in this "centre."

The questions in the preceding paragraph almost suggest that to problematize the character of Hamlet one need not read all of Hamlet - just the Player's speech and its analogues in the play. But my questions are intended to emphasize that the Aeneid is in Hamlet as breath is in a living body. This assertion will surprise no one. The fragment of the old, never-acted play embodying Aeneas' tale to Dido confirms, if confirmation is needed, that the Ghost's story is epic. Like the Ghost's story the old play says what kind of warfare (or theatre of war) is figured in Hamlet, where Shakespeare maps his protagonist's single-handed and mental fight into the configurations of a classical and an early modern siege conflict. And knowing how classical texts and contemporary treatises presented the tactics, the intelligence-gathering 
and the drawn-out nature of siege campaigns, perhaps we may regard Hamlet's much-discussed "delay" and "hesitation" as reflecting the necessary and realistic elements of the kind of siege struggle in which he sees himself enlisted.

\section{University of Calgary}

\section{Notes}

1. Donna B. Hamilton, Virgil and "The Tempest": The Politics of Imitation (Columbus: Ohio State University Press, 1990).

2. Hamilton, p. xiii.

3. Mikhail M. Bakhtin, Speech Genres And Other Late Essays. Trans. Vern W. McGee, ed. Caryl Emerson and Michael Holquist (Austin: University of Texas Press, 1986), p. 98.

4. All Hamlet quotations are from the Oxford Shakespeare, ed. G.R. Hibbard (Oxford: Oxford University Press, 1987).

5. Hamilton, 4,13 .

6. All references to the Aeneid cite the line numbering in the Robert Fitzgerald translation (New York: Random House, 1983).

7. Christopher Marlowe, Dido Queen of Carthage and The Massacre at Paris, ed. H.J.Oliver (Cambridge: Harvard University Press, 1968), II.i.254n.

8. In the Arden edition of Hamlet (London \& New York: Methuen, 1982), p. 479.

9. Qtd. Hamilton, 46. See also Lionel Tennenhouse, Power on Display: The Politics of Shakespeare's Genres (New York and London: Methuen, 1986), 103-115, and Peter Stallybrass, "Patriarchal Territories: The Body Enclosed." Rewriting the Renaissance: The Discourses of Sexual Difference in Early Modern Europe. Ed. Margaret W. Ferguson, Maureen Quilligan and Nancy J. Vickers (Chicago and London: University of Chicago Press, 1986), 123-42.

10. J.R. Hale, Renaissance Fortification: Art or Engineering? Walter Neurath Memorial Lecture 8 (London: Thames and Hudson, 1977), p. 41.

11. Hale, p. 42.

12. Hamilton, p. 86.

13. Hibbard, Hamlet II.ii.437-33n.

14. Bakhtin, p. 99.

15. Harold Bloom, The Anxiety of Influence (Oxford: Oxford University Press, 1973), p. 11. 16. Hamilton, p. 134.

17. Christopher Duffy, Siege Warfare: The Fortress in the Early Modern World 1494-1660 
28 / Renaissance and Reformation / Renaissance et Réforme

(London and Henley: Routledge \& Kegan Paul, 1979), p. 90, 141.

18. Duffy, pp. 71-72.

19. Duffy, p. 76.

20. See Duff Cooper, Sergeant Shakespeare (London: Hart-Davis, 1949), pp. 32-36.

21. Two woodcut illustrations are in J.R. Hale, The Art of War and Renaissance England. Folger Booklet on Tudor and Stuart Civilization (Charlottesville: University Press of Virginia, 1968), p. 13.

22. Jenkins, Arden Hamlet, I.iii.122n.

23. Niccolò Machiavelli, The Art of War. Trans. Ellis Farneworth, ed. Neal Wood (Indianapolis, New York, Kansas City: Bobbs-Merrill, Inc., 1965), pp. 195-97.

24. Oliver, Introduction to Dido, xlii-xliii.

25. Jenkins, Arden Hamlet, 478.

26. Patricia Fumerton, Cultural Aesthetics: Renaissance Literature and the Practice of Social Ornament (Chicago and London: University of Chicago Press, 1991), p. 69.

27. Tennenhouse, pp. 112-13.

28. Machiavelli, p. 186.1 